\title{
Antibodies in the Pathogenesis of Hypertension
}

\author{
Christopher T. Chan, ${ }^{1}$ Maggie Lieu, ${ }^{1}$ Ban-Hock Toh, ${ }^{2}$ Tin S. Kyaw, ${ }^{3}$ \\ Alexander Bobik, ${ }^{3}$ Christopher G. Sobey, ${ }^{1}$ and Grant R. Drummond ${ }^{1}$ \\ ${ }^{1}$ Vascular Biology \& Immunopharmacology Group, Department of Pharmacology, Monash University, Clayton, VIC 3800, Australia \\ ${ }^{2}$ Centre for Inflammatory Diseases, Department of Medicine, Southern Clinical School, Monash University, Clayton, VIC, Australia \\ ${ }^{3}$ Vascular Biology \& Atherosclerosis Laboratory, Baker IDI Heart and Diabetes Institute, Melbourne, VIC, Australia
}

Correspondence should be addressed to Grant R. Drummond; grant.drummond@monash.edu

Received 8 April 2014; Revised 21 May 2014; Accepted 4 June 2014; Published 23 June 2014

Academic Editor: Tomasz Guzik

Copyright (C) 2014 Christopher T. Chan et al. This is an open access article distributed under the Creative Commons Attribution License, which permits unrestricted use, distribution, and reproduction in any medium, provided the original work is properly cited.

It has long been known that circulating levels of $\operatorname{IgG}$ and $\operatorname{IgM}$ antibodies are elevated in patients with essential and pregnancyrelated hypertension. Recent studies indicate these antibodies target, and in many cases activate, G-protein coupled receptors and ion channels. Prominent among these protein targets are $\mathrm{AT}_{1}$ receptors, $\alpha_{1}$-adrenoceptors, $\beta_{1}$-adrenoceptors, and L-type voltage operated $\mathrm{Ca}^{2+}$ channels, all of which are known to play key roles in the regulation of blood pressure through modulation of vascular tone, cardiac output, and/or $\mathrm{Na}^{+}$/water reabsorption in the kidneys. This suggests that elevated antibody production may be a causal mechanism in at least some cases of hypertension. In this brief review, we will further describe the protein targets of the antibodies that are elevated in individuals with essential and pregnancy-related hypertension and the likely pathophysiological consequences of antibody binding to these targets. We will speculate on the potential mechanisms that underlie elevated antibody levels in hypertensive individuals and, finally, we will outline the therapeutic opportunities that could arise with a better understanding of how and why antibodies are produced in hypertension.

\section{Introduction}

Hypertension is defined as chronically elevated blood pressures of $>140 / 90 \mathrm{mmHg}$. Two of the most common forms of the condition are essential hypertension, where the underlying cause is unknown, and preeclampsia or pregnancyrelated hypertension. For several decades it has been known that both essential and pregnancy-related hypertension are associated with elevated serum levels of antibodies [1-4]. More recently, studies in humans and animal models of each condition have begun to identify the protein targets of these antibodies as receptors and ion channels with key roles in the regulation of blood pressure. Such studies not only offer insights into the mechanisms by which antibodies might contribute to hypertension but they also highlight potential new avenues for the clinical management of hypertension. In this brief review we will summarise the evidence in support of a role for antibodies in the pathophysiology of essential hypertension and preeclampsia. We will discuss the protein targets of the antibodies that have been identified in hypertensive individuals and provide some potential explanations for why the production of these antibodies may be elevated. Finally, we will speculate on how such findings may translate into improved clinical management of hypertension.

\section{Antibodies as Causes of Disease}

Antibodies, or immunoglobulins (Ig), are produced exclusively by $B$ cells as part of the mammalian adaptive immune response [5]. Antibodies play a crucial role in adaptive immunity through their ability to bind antigens, which are normally toxic substances or fragments of pathogen-derived proteins. Such binding results in either neutralisation of the antigen itself or, when the antigen is bound to a cell (e.g., bacteria), destruction of that cell via activation of the complement system, neutrophil degranulation, or phagocytosis by macrophages (Figure 1). 


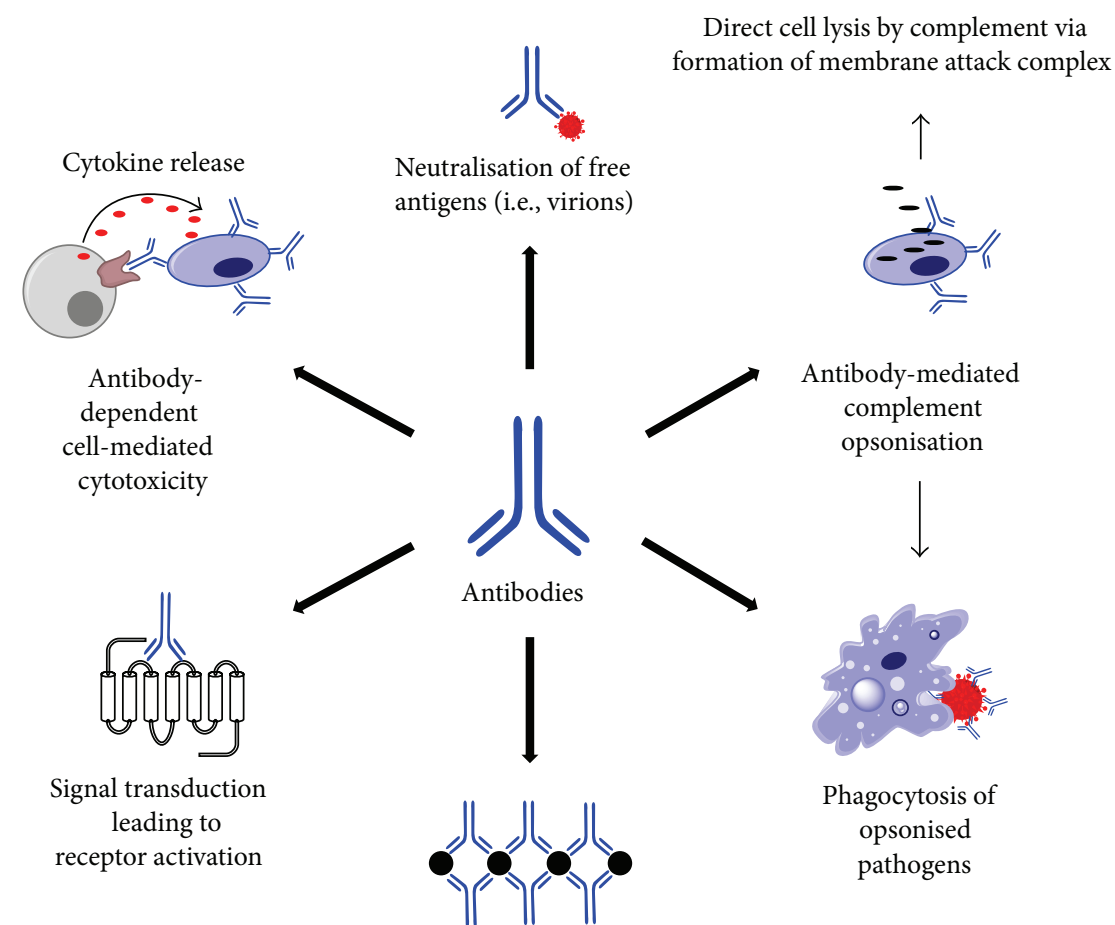

Formation of proinflammatory

immune complexes

FIGURE 1: Schematic diagram showing the various types of antibody-mediated autoimmune responses.

For B cells to generate and secrete antibodies, they must first undergo differentiation into plasma cells. Naïve $B$ cells detect antigens via their $B$ cell receptors, which are membrane-bound immunoglobulins (IgM) with unique and randomly-generated antigen-binding sites [6]. Following binding, the antigen is internalised, processed, and displayed by major histocompatibility class II (MHC II) proteins on the extracellular surface of the B cell [6]. The next step in $\mathrm{B}$ cell differentiation involves the detection of the MHC IIpresented antigen by the T cell receptor (TCR) of an activated $\mathrm{T}$ helper $\left(\mathrm{T}_{\mathrm{H}}\right)$ cell that has previously encountered the same antigen. The $\mathrm{T}_{\mathrm{H}}$ cell also provides essential costimulatory signals in the form of interactions between its CD40 ligand and the CD40 receptor on the B cell [7], as well as cytokines such as interferon-gamma and interleukin-4 [8]. Together, these signals ultimately promote the differentiation of the $\mathrm{B}$ cell into an antibody-secreting plasma cell. Such signals also play a crucial role in isotype switching (e.g. IgM $\rightarrow \operatorname{IgG}$ ) [9], which allows the generated antibodies to interact with different effector molecules and thereby direct the type of immune response that is mounted.

Although antibodies normally target foreign molecules, under some circumstances they may be raised against hostderived molecules. Such a loss of recognition of "self" is the basis for autoimmune diseases. There are several mechanisms by which aberrant antibody production can lead to autoimmune pathologies (Figure 1). For example, the binding of antibodies to antigens expressed on the surface of endogenous cells may lead to the destruction of these cells via complement- or leukocyte-dependent interactions. This type of response is termed a "Type II Hypersensitivity reaction" and is the cause of the loss of erythrocytes in autoimmune haemolytic anaemia [10]. Alternatively, "Type III Hypersensitivity reactions" involve the recognition of soluble antigens in the host by antibodies and the subsequent formation of "immune complexes." Immune complexes are cross-linked aggregations of antibodies and antigens that can be deposited in various tissues to cause local inflammatory responses [11]. Immune complexes are a hallmark of several autoimmune disorders including vasculitis and systemic lupus erythematosus where deposition of such complexes in the kidneys gives rise to glomerulonephritis $[12,13]$. Finally, some autoimmune diseases are associated with the formation of nonimmunogenic, agonistic antibodies to receptors [14]. These types of diseases are often classified as "Type V Hypersensitivity Reactions." Agonistic antibodies stimulate receptors in a similar fashion to their cognate ligands and thus lead to overstimulation of the specific system involved. Myasthenia gravis is an example of an autoimmune disease caused by the generation of agonistic antibodies against nicotinic receptors $[14,15]$.

\section{Protein Targets of Hypertension-Related Antibodies}

Studies dating back to the 1970s demonstrated that essential hypertension in humans is associated with elevated IgG and IgM titres [1-4]. However, these early studies did not 
identify the targets of these antibodies and thus provided no indication of whether they were important to the pathophysiology of hypertension. Studies from around the same time on animal models confirmed that hypertension was associated with an increase in antibody production and even went some way towards implicating a possible causative role for these antibodies. For example, Ba et al. identified autoantibodies in the serum of spontaneously hypertensive rats (SHRs) that were cytotoxic to $\mathrm{T}$ cells. Although the authors did not establish a precise mechanism by which these antibodies contribute to hypertension, they implied that the antibodies might induce apoptosis of "suppressor" $\mathrm{T}$ cells that normally prevent damage to the vascular wall and thus protect against cardiovascular disease [16]. In a separate study, it was shown that rats with hypertension induced by renal infarction had high serum levels of antibodies that bound to arteries, glomeruli, and basement membranes of the kidneys [17]. Given the key roles of the kidney and vasculature in the regulation of hemodynamic parameters, this latter study provided an indication that elevated antibody production may actually contribute to the chronic elevation in blood pressure that defines hypertension. And indeed, more recent work identifying the specific molecular targets of the antibodies present in individuals with essential hypertension and preeclampsia not only supports this idea, but also begins to shed light on how elevated antibody production might contribute to elevated blood pressure.

3.1. Angiotensin II Type-1 Receptors. The angiotensin II type-1 receptor $\left(\mathrm{AT}_{1} \mathrm{R}\right)$ plays a crucial role in the regulation of blood pressure [18]. Stimulation of the $\mathrm{AT}_{1} \mathrm{R}$ by its cognate ligand, angiotensin II, results in vascular smooth muscle cell (VSMC) contraction and proliferation, release of aldosterone from the adrenal glands, and activation of the sympathetic nervous system $[18,19]$. Furthermore, it has recently been discovered that $\mathrm{AT}_{1}$ receptor activation on $\mathrm{T}$ lymphocytes promotes a proinflammatory phenotype that contributes to hypertension [20].

$\mathrm{AT}_{1} \mathrm{R}$-activating IgG autoantibodies ( $\mathrm{AT}_{1}-\mathrm{AAs}$ ) directed against the second extracellular loop of the $\mathrm{AT}_{1} \mathrm{R}$ are prevalent in over $95 \%$ of patients with pregnancy-associated hypertension, and antibody titres correlate positively with disease severity $[21,22]$. $\mathrm{AT}_{1}$-AAs appear to activate a cascade of proinflammatory cytokines that contribute directly to hypertension in preeclampsia [23]. In vivo administration of $\mathrm{AT}_{1}$-AAs isolated from preeclamptic humans to pregnant mice was shown to induce hypertension in those animals [24]. Furthermore, $\mathrm{AT}_{1}-\mathrm{AA}$ treatment causes an increase in the circulating levels of tumour necrosis factor- $\alpha$ and interleukin- 6 in pregnant mice and inhibition of these cytokines with neutralising antibodies blunts hypertension $[24,25]$.

$\mathrm{AT}_{1}$-AAs have also been identified in a subset of individuals with essential hypertension [26-28]. These $\mathrm{AT}_{1}-\mathrm{AAs}$ appear to be similar in function and specificity as those identified in preeclamptic patients as they also bind to the second extracellular loop of the $\mathrm{AT}_{1} \mathrm{R}[26,28]$. The fact that essential hypertensive patients with $\mathrm{AT}_{1}$-AAs respond with greater blood pressure reductions to $\mathrm{AT}_{1} \mathrm{R}$ blockade by candesartan than hypertensive individuals without $\mathrm{AT}_{1}-\mathrm{AA}$ $[29,30]$ suggests a causal role for $\mathrm{AT}_{1}$-AAs in at least some cases of hypertension.

3.2. Alpha-1 Adrenergic Receptors. The alpha-1 adrenergic receptor $\left(\alpha_{1} \mathrm{AR}\right)$ is a G-protein coupled receptor that is primarily expressed on VSMCs and proximal renal tubules [31]. Activation of the $\alpha_{1} \mathrm{AR}$ by its endogenous ligands, noradrenaline and adrenaline, or synthetic compounds such as phenylephrine, results in VSMC contraction and increased total peripheral resistance, as well as increased $\mathrm{Na}^{+}$reabsorption in the kidney causing elevated blood pressure [32]. IgG receptor-activating autoantibodies against the $\alpha_{1} \mathrm{AR}$ $\left(\alpha_{1}\right.$ AR-AA) have been described in patients with essential hypertension [28, 33-35]. Unlike $\mathrm{AT}_{1}$-AAs, which appear to bind to a similar domain of the $\mathrm{AT}_{1} \mathrm{R}$ (i.e., the second extracellular loop) irrespective of the patient from which they were derived, $\alpha_{1}$ AR-AA from different patients display selectivity towards separate regions of the receptor, with antibodies from some individuals targeting the first extracellular loop, and antibodies from other individuals targeting the second extracellular loop $[33,34]$. It is unclear whether these varying binding properties have implications for the ability of a specific antibody to modulate receptor function. It is also unclear whether $\alpha_{1}$ AR-AAs are present or elevated in individuals with preeclampsia.

3.3. Beta-1 Adrenergic Receptors. The $\beta$-1 adrenergic receptor ( $\left.\beta_{1} \mathrm{AR}\right)$ shares the same endogenous agonists with $\alpha_{1}$ ARs but differs in ligand affinity, tissue distribution, and functional outcomes following stimulation. $\beta_{1}$ ARs are localised predominately in cardiac tissue where activation results in increased heart rate and contractility and an overall increase in cardiac output [36]. Cardiac output is a major determinant of blood pressure and thus $\beta_{1} \mathrm{AR}$ blockers have long been used as antihypertensive agents [37]. $\beta_{1}$ AR agonistic IgG autoantibodies ( $\beta_{1}$ AR-AA) against the second extracellular loop of the receptors were detected in the serum of spontaneously hypertensive rats [38]. Furthermore, injection of $\beta_{1}$ AR-AAs into healthy Lewis rats promoted cardiomyopathy and increases in systolic blood pressure [39]. Although evidence for the presence of $\beta_{1}$ AR-AAs in human essential hypertension and preeclampsia is lacking, these antibodies have been identified in patients with idiopathic dilated cardiomyopathy [40].

3.4. L-Type Voltage Gated Calcium Channels. L-type voltage gated calcium channels (L-type VOCCs) are expressed on VSMCs in resistance vessels and, in their open state, directly contribute to vascular tone and blood pressure by facilitating the influx of extracellular $\mathrm{Ca}^{2+}$ [41]. It is well established that L-type VOCC expression in the vasculature is upregulated in experimental hypertension and that this contributes to increased $\mathrm{Ca}^{2+}$ levels in VSMCs and thus elevated vascular resistance [42-47]. The importance of Ltype VOCCs in human hypertension is highlighted by the fact that inhibitors of these channels (e.g., nifedipine) continue to 


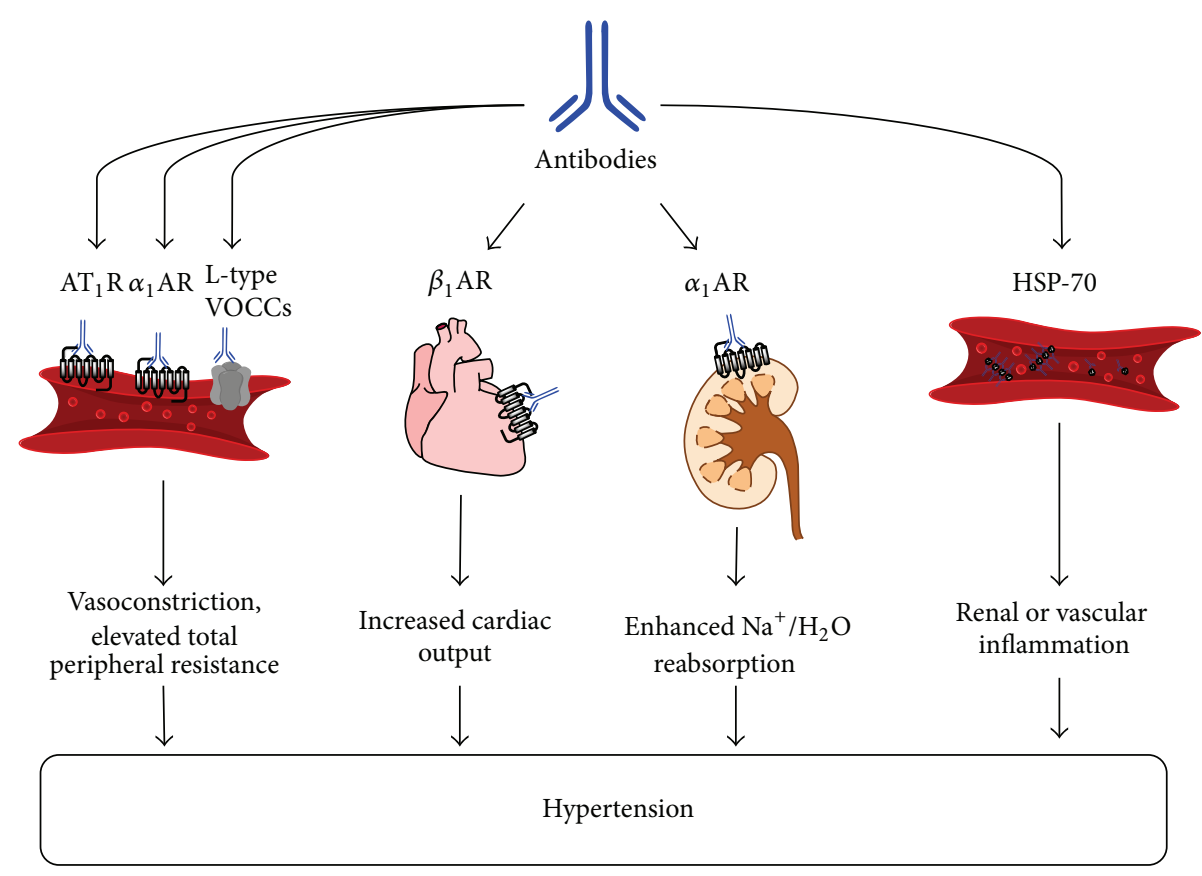

FIGURE 2: Schematic diagram showing the mechanism by which autoantibodies may promote increases in vascular tone, cardiac output, $\mathrm{Na}^{+}$/water reabsorption, and renal and vascular inflammation, and thereby contribute to hypertension.

represent one of the most effective and widely-used classes of antihypertensive medications [48]. Thus, it is noteworthy that autoantibodies against L-type VOCCs were identified in some patients with essential hypertension [49]. Although the authors did not examine the effect of these antibodies on L-type VOCC function, a separate study demonstrated increased intracellular $\mathrm{Ca}^{2+}$ influx in pancreatic islet cells following the binding of analogous IgG and IgA autoantibodies to L-type VOCCs in the setting of Type-1 diabetes [50]. This implies that antibodies against L-type VOCCs are likely to be agonistic in nature and could thus contribute to increased VSMC Ca ${ }^{2+}$ influx in hypertension.

3.5. Heat Shock Proteins. Heat shock proteins (HSPs) are a family of highly-conserved proteins that provide protection against danger-related signals by acting as molecular chaperones to assist in the folding and trafficking of proteins during cellular stress [51]. Among the multitude of known mammalian HSPs, HSP-70 has received most attention in the field of hypertension research. First, in vitro exposure of cultured VSMCs, endothelial cells or isolated aortic rings to hypertension-relevant stimuli such as oxidative stress, cyclic strain, and angiotensin II, induces the expression of HSP-70 [52-54]. Second, levels of HSP-70 and HSP-70-reactive CD4 $\mathrm{T}$ cells are elevated in the kidneys in several rat models of hypertension [55-57]. Finally, HSP-70 serum concentrations are elevated in pregnancy-associated hypertension and are positively correlated with blood pressure in affected women [58].
Elevated levels of $\operatorname{IgG}$ and $\operatorname{IgA}$ antibody titres against HSP-70 have been identified in essential hypertensive individuals $[59,60]$. Surprisingly, elevated anti-HSP-70 antibody levels in essential hypertension were not associated with changes in serum HSP-70 in these patients [60]. Thus, the function of anti-HSP-70 antibodies in essential hypertension remains unclear. It is possible that anti-HSP-70 antibodies could either promote inflammation via formation of circulating immune complexes or, alternatively, alleviate the proinflammatory actions of these proteins via neutralisation. A more recent study by Molvarec et al. was unable to demonstrate any changes in circulating levels of anti-HSP-70 antibodies in women with preeclampsia [61].

3.6. Miscellaneous. A study in borderline hypertensive patients described a reduction in circulating levels of antioxidised LDL IgG antibodies [62]. However, a follow-up investigation failed to detect any difference in levels of these antibodies between patients with clinical hypertension and normotensive controls [63], and thus the significance of anti-oxidised LDL antibodies in the pathophysiology of hypertension is unclear. Other studies in borderline hypertensive individuals detected elevations in circulating antiendothelial cell IgG and IgM antibodies [64-66]. While data in the setting of human essential hypertension is still missing, these antibodies have been identified in women with severe preeclampsia and have been proposed to contribute to endothelial dysfunction [67].

Figure 2 provides a summary of the targets of antibodies that have been shown to be elevated in hypertension and 
the potential mechanisms by which these antibodies may contribute to disease pathophysiology.

\section{Mechanisms Contributing to Antibody Production}

The previous discussion highlighting the association of hypertension with increased antibody levels raises the question: what are the mechanisms involved in antibody production during hypertension? There are at least three possible explanations including (1) neoantigen formation; (2) molecular mimicry; and/or (3) aberrant B cell function.

4.1. Neoantigen Formation. Harrison and colleagues recently put forward a hypothesis whereby "neoantigens" were highlighted as the central mediators of the immune cell activation that underlies hypertension $[68,69]$. These authors suggested that hypertensive stimuli such as Ang II, catecholamines, and aldosterone initially induce a moderate increase in blood pressure via their "classical" actions in promoting $\mathrm{Na}^{+} /$water retention, vasoconstriction, and/or increased sympathetic drive $[68,69]$. This moderate increase in blood pressure is postulated to cause both mechanical and oxidative stress in the walls of blood vessels and also in the kidneys, leading to structural and chemical modifications to proteins such that they are no longer recognised as "self," but rather as neoantigens. These neoantigens are predicted to then invoke an adaptive immune response, leading to vascular and renal inflammation and exacerbation of hypertension $[68,69]$. However, it is presently unclear whether any of the proteins that have been identified as targets of antibodies in hypertensive animals and humans (e.g., $\mathrm{AT}_{1} \mathrm{R}, \alpha_{1} \mathrm{AR}, \beta_{1} \mathrm{AR}$, L-type VOCCs, or HSP-70) undergo structural or chemical alterations that may render them as potential neoantigens.

4.2. Molecular Mimicry. Another possible explanation for autoantibody production in hypertension involves molecular mimicry, where foreign or pathogen-derived antigens trigger an immune response against "self" peptides of similar homology [70]. A prominent example of this is myasthenia gravis, an autoimmune disease where agonistic antibodies are raised against nicotinic receptors $[14,15]$. These antibodies show strong cross-reactivity to herpes simplex virus glycoprotein $\mathrm{D}$ [15].

Relating to hypertension, $\mathrm{AT}_{1}$-AAs from women with preeclampsia were shown to recognise the VP2 caspid protein from parvovirus B19 [71]. The seroprevalence of this virus has been reported to be more than $70 \%$ of the adult population $[72,73]$, and its involvement in predisposing infected individuals to various autoimmune disorders has been recognised [73]. Thus, it is plausible that molecular mimicry underlies the elevations in $\mathrm{AT}_{1}$-AAs observed in preeclampsia [74] and essential hypertension.

Although not examined in the setting of hypertension, there is evidence in other disease states that antibodies against L-type VOCCs and $\beta_{1}$ ARs may also arise as a result of molecular mimicry. For example, autoantibodies against Ltype VOCCs that are present in a subset of individuals with Type-1 diabetes also recognise the B4 VP1 protein of the coxsackievirus [50]. Interestingly, the seroprevalence of coxsackievirus infection was reported to positively associate with the incidence of hypertension in a Chinese Mongolian population [75]. Furthermore, $\beta_{1}$ AR-AAs were demonstrated to recognise the carboxy-terminus of the ribosomal P0 and P2 proteins from Trypanosoma cruzi, the parasite that is responsible for chronic Chagas heart disease [76-79]. Conversely, autoantibodies against human ribosomal $\mathrm{P}$ proteins that are present in patients with systemic lupus erythematosus cross-react with (but do not activate) the $\beta_{1} \mathrm{AR}$ [78]. These findings may suggest that a high degree of sequence and/or structural homology exists between $\beta_{1} \mathrm{AR}$ and ribosomal $\mathrm{P}$ proteins.

4.3. Aberrant B Cell Function. Hypertensive stimuli such as Ang II might act to directly modify the function of $\mathrm{B}$ cells, such that their capacity to produce antibodies is enhanced. $\mathrm{Na}^{+} / \mathrm{H}^{+}$ion exchangers (NHEs) are critical regulators of intracellular $\mathrm{pH}$ and are crucial to a variety of fundamental cellular processes such as proliferation, growth, and migration [80]. Studies from the 1990s demonstrated that B cells isolated from a subset of hypertensive patients display heightened activity of NHEs [81, 82]. Moreover, these B cells were further characterised as having enhanced G-protein activation, a higher proliferative capacity, and augmented IgG and IgM antibody secretion compared to $B$ cells from nonhypertensive individuals [83, 84]. While the mechanism underlying this increase in NHE activity in B cells was not explored, in other cell types (e.g., VSMCs and cardiomyocytes) it is known that $\mathrm{AT}_{1} \mathrm{R}$ stimulation can enhance NHE activity [85-87]. Indeed, $B$ cells express $\mathrm{AT}_{1} \mathrm{R}$ [88] and we have preliminary data showing that stimulation of B cells isolated from mice with Ang II potentiates IgM formation in response to a known B cell stimulator, the oligodeoxynucleotide CpG (Figure 3). Thus, amplified antibody production may arise as a result of elevated NHE function due to the direct activation of $\mathrm{AT}_{1} \mathrm{R}$ expressed on $\mathrm{B}$ cells.

\section{The Role of B Cells in Hypertension}

Implicit in the previous discussion on antibodies in hypertension is a potentially important role for the cell type that produces antibodies, namely, B cells. In their seminal study, Guzik et al. showed that recombinase-activating gene1 knockout $\left(\mathrm{RAGl}^{-/-}\right.$) mice-which lack $\mathrm{T}$ and $\mathrm{B}$ cellsdisplayed a blunted hypertensive response to both Ang II and deoxycorticosterone acetate/salt [89]. Whereas adoptive transfer of $\mathrm{T}$ cells into $\mathrm{RAGl}^{-/-}$mice recapitulated the full hypertensive effects of Ang II, transfer of B cells had no effect [89]. There are at least two potential explanations for the lack of effect of B cell adoptive transfer in Ang II-treated RAG1 ${ }^{-/-}$ mice. First, it is possible that the adoptively transferred B cells did not engraft in sufficient numbers to influence immune function. Indeed, in a previous study it was shown that retroviral-mediated reintroduction of the RAG1 gene into 


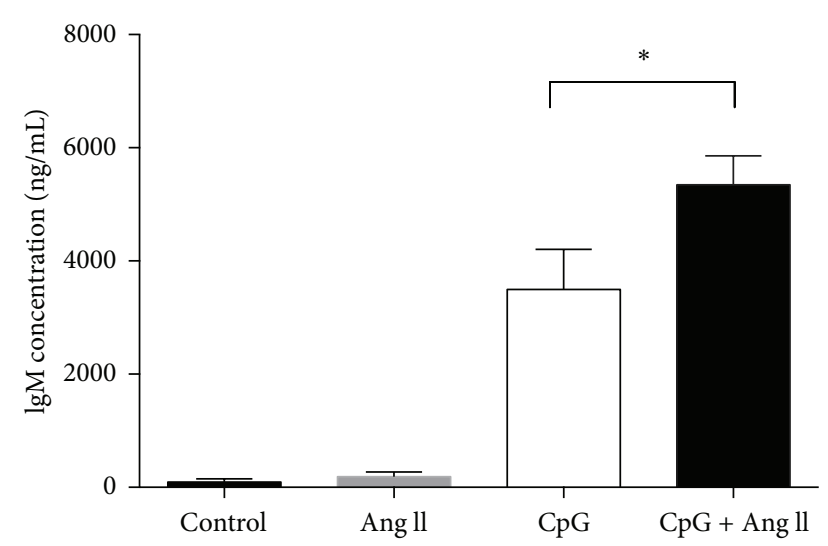

Figure 3: Effect of angiotensin II (Ang II; $0.1 \mu \mathrm{M}, 48 \mathrm{~h}$ ) or CpG oligodeoxynucleotides (CpG; $5 \mu \mathrm{g} / \mathrm{mL}, 48 \mathrm{~h}$ ) alone or in combination on IgM antibody secretion from primary cultures of mouse $\mathrm{B}$ cells. Values represent mean \pm S.E.M. of $n=14$ experiments. ${ }^{*} P<0.05$ for Bonferroni's post-hoc test after one-way ANOVA.

$\mathrm{RAGl}^{-/-}$mice restored T cells numbers back to levels in wildtype mice, while B cell numbers only increased marginally [90]. This suggests that the immunological environment in $\mathrm{RAGl}^{-1-}$ mice, while being favourable to the survival and function of $\mathrm{T}$ cells, may be incompatible with the growth and function of $\mathrm{B}$ cells. An alternative explanation may lie in the different mechanisms that activate $\mathrm{T}$ cells and $\mathrm{B}$ cells during an immune response. Whilst activation of $\mathrm{T}$ cells relies primarily on antigen presentation from innate immune cells such as dendritic cells (which are relatively unaffected in $\mathrm{RAGl}^{-/-}$mice), as discussed previously, B cell activation and differentiation into an effector phenotype normally requires interactions with $\mathrm{T}_{\mathrm{H}}$ cells [6]. Hence, the lack of $\mathrm{T}$ cells in $\mathrm{RAGl}^{-/-}$mice may have precluded the possibility of any adoptively transferred $\mathrm{B}$ cells becoming activated. Indeed, a critical role of $\mathrm{T}_{\mathrm{H}}$ cells in $\mathrm{B}$ cell activation during hypertension was suggested in a recent study showing that adoptive transfer of $\mathrm{T}_{\mathrm{H}}$ cells from preeclamptic mice into normal pregnant mice induced $\mathrm{AT}_{1}$-AA production and elevated blood pressure [91]. Importantly, a B cell depleting agent ameliorated both of these effects [91].

\section{Therapeutic Implications}

An understanding of the role of B cells and antibody production during hypertension could aid in the refinement of current treatment approaches and also in development of novel antihypertensive therapies. For example, by identifying the autoantibodies that are specifically elevated in a given hypertensive patient, it might be possible to "tailor" the way their disease is subsequently managed for better clinical outcomes; that is, individuals with $\mathrm{AT}_{1}$-AAs would favourably respond to $\mathrm{AT}_{1} \mathrm{R}$ blockers over patients with $\mathrm{L}$ type VOCC autoantibodies, where calcium channel blockers such as nifedipine would be preferred.

In terms of new therapeutic approaches, identification of the specific pathogen-derived or neoantigens that lead to elevated antibody generation in hypertension could lead to immunisation strategies aimed at neutralising such antigens or steering the immune response away from one that promotes hypertension. Indeed, two vaccines against Ang II have been developed and showed some early promise in reducing blood pressure in hypertensive patients [92]. However, due to their lower efficacy compared to conventional inhibitors of the renin-angiotensin system, the vaccines did not proceed into Phase III clinical trials $[93,94]$, and thus further work is needed to determine if alternative immunisation strategies (i.e., involving different adjuvants and/or immunogens) will be more effective.

$\mathrm{B}$ cell-depleting agents, which include antibodies against the $B$ cell specific surface receptor $C D 20$ and the $B$ cell activating factor BAFF, are already in clinical use for the treatment of autoimmune diseases such as lupus erythematosus [95] and could potentially be used to treat hypertension. Of course, these drugs have the potential for causing immunosuppression and hence their use might be best reserved for those hypertensive patients that do not respond to conventional therapies. Until recently, one of the main therapeutic options for individuals with resistant hypertension was surgical denervation of the renal artery [96]; however, the effectiveness of this procedure has recently been called into question [97]. Thus, B cell-modulating drugs might yet be a safer and more efficacious therapeutic option for such patients.

\section{Conclusion}

There is evidence that circulating antibody levels are elevated in both essential and pregnancy-related hypertension. Many of these antibodies appear to target receptors and ion channels known to be involved in the regulation of blood pressure. Further studies are required to characterise the precise impact that antibody binding has on the function of these proteins and to uncover the mechanisms responsible for aberrant antibody production in hypertension. Such studies should not only allow us to evaluate the significance of elevated antibody production in the pathophysiology of hypertension, but they may also lead to the development of new therapeutic approaches and/or the refinement of current approaches, to improve the management of clinical hypertension in the future.

\section{Conflict of Interests}

The authors declare that there is no conflict of interests regarding the publication of this paper.

\section{Acknowledgments}

Christopher T. Chan is supported by an Australian Postgraduate Award (ID no. 5131432). Grant R. Drummond and Christopher G. Sobey are supported by Senior Research Fellowships from the National Health and Medical Research Council of Australia (NHMRC; ID nos. APP1006017 and 350327 , resp.). None of these funding sources had any role in 
the writing of the report or in the decision to submit the paper for publication.

\section{References}

[1] A. Ebringer and A. E. Doyle, "Raised serum IgG levels in hypertension," British Medical Journal, vol. 2, no. 5702, pp. 146148, 1970.

[2] P. Suryaprahba, T. Padma, and U. Brahmaji Rao, "Increased serum IgG levels in essential hypertension," Immunology Letters, vol. 8, no. 3, pp. 143-145, 1984.

[3] E. Hilme, H. Herlitz, T. Soderstrom, and L. Hansson, "Increased secretion of immunoglobulins in malignant hypertension," Journal of Hypertension, vol. 7, no. 2, pp. 91-95, 1989.

[4] T. Gudbrandsson, L. Hansson, H. Herlitz, L. Lindholm, and L. A. Nilsson, "Immunological changes in patients with previous malignant essential hypertension," Lancet, vol. 1, no. 8217, pp. 406-408, 1981.

[5] T. W. Lebien and T. F. Tedder, "B lymphocytes: How they develop and function," Blood, vol. 112, no. 5, pp. 1570-1580, 2008.

[6] D. C. Parker, “T cell-dependent B cell activation," Annual Review of Immunology, vol. 11, pp. 331-360, 1993.

[7] I. S. Grewal and R. A. Flavell, "CD40 and CD154 in cellmediated immunity," Annual Review of Immunology, vol. 16, pp. 111-135, 1998.

[8] J. Purkerson and P. Isakson, "A two-signal model for regulation of immunoglobulin isotype switching," The FASEB Journal, vol. 6, no. 14, pp. 3245-3252, 1992.

[9] S. G. Tangye, A. Ferguson, D. T. Avery, C. S. Ma, and P. D. Hodgkin, "Isotype switching by human B cells is divisionassociated and regulated by cytokines," Journal of Immunology, vol. 169, no. 8, pp. 4298-4306, 2002.

[10] B. C. Gehrs and R. C. Friedberg, "Autoimmune hemolytic anemia," The American Journal of Hematology, vol. 69, no. 4, pp. 258-271, 2002.

[11] A. N. Theofilopoulos and F. J. Dixon, "Immune complexes in human diseases," The American Journal of Pathology, vol. 100, no. 2, pp. 529-594, 1980.

[12] D. Koffler, V. Agnello, R. Thoburn, and H. G. Kunkel, "Systemic lupus erythematosus: prototype of immune complex nephritis in man," Journal of Experimental Medicine, vol. 134, supplement 3, pp. 169S-179S, 1971.

[13] W. L. Gross, A. Trabandt, and E. Reinhold-Keller, "Diagnosis and evaluation of vasculitis," Rheumatology, vol. 39, no. 3, pp. 245-252, 2000.

[14] J. M. Lindstrom, M. E. Seybold, V. A. Lennon, S. Whittingham, and D. D. Duane, "Antibody to acetylcholine receptor in myasthenia gravis: prevalence, clinical correlates, and diagnostic value," Neurology, vol. 51, no. 4, p. 933, 1998.

[15] P. L. Schwimmbeck, T. Dyrberg, D. B. Drachman, and M. B. A. Oldstone, "Molecular mimicry and myasthenia gravis. An autoantigenic site of the acetylcholine receptor $\alpha$-subunit that has biologic activity and reacts immunochemically with herpes simplex virus," Journal of Clinical Investigation, vol. 84, no. 4, pp. 1174-1180, 1989.

[16] D. Ba, N. Takeichi, T. Kodama, and H. Kobayashi, "Restoration of $\mathrm{T}$ cell depression and suppression of blood pressure in spontaneously hypertensive rats (SHR) by thymus grafts or thymus extracts," Journal of Immunology, vol. 128, no. 3, pp. 12111216, 1982.
[17] F. N. White and A. Grollman, "Autoimmune factors associated with infarction of the kidney," Nephron, vol. 204, pp. 93-102, 1964.

[18] M. J. Peach, "Renin angiotensin system: biochemistry and mechanisms of action," Physiological Reviews, vol. 57, no. 2, pp. 313-370, 1977.

[19] L. Hunyady and K. J. Catt, "Pleiotropic AT1 receptor signaling pathways mediating physiological and pathogenic actions of angiotensin II," Molecular Endocrinology, vol. 20, no. 5, pp. $953-$ 970, 2006.

[20] J. L. Silva-Filho, M. C. Souza, M. D. G. Henriques et al., "AT1 receptor-mediated angiotensin II activation and chemotaxis of T lymphocytes," Molecular Immunology, vol. 48, no. 15-16, pp. 1835-1843, 2011.

[21] G. Wallukat, V. Homuth, T. Fischer et al., "Patients with preeclampsia develop agonistic autoantibodies against the angiotensin AT1 receptor," Journal of Clinical Investigation, vol. 103, no. 7, pp. 945-952, 1999.

[22] A. H. Siddiqui, R. A. Irani, S. C. Blackwell, S. M. Ramin, R. E. Kellems, and Y. Xia, "Angiotensin receptor agonistic autoantibody is highly prevalent in preeclampsia: correlation with disease severity," Hypertension, vol. 55, no. 2, pp. 386-393, 2010.

[23] Y. Xia and R. E. Kellems, "Angiotensin receptor agonistic autoantibodies and hypertension : preeclampsia and beyond," Circulation Research, vol. 113, no. 1, pp. 78-87, 2013.

[24] C. C. Zhou, R. A. Irani, Y. Dai et al., "Autoantibody-mediated IL-6-dependent endothelin-1 elevation underlies pathogenesis in a mouse model of preeclampsia," Journal of Immunology, vol. 186, no. 10, pp. 6024-6034, 2011.

[25] R. A. Irani, Y. Zhang, C. C. Zhou et al., "Autoantibody-mediated angiotensin receptor activation contributes to preeclampsia through tumor necrosis factor- $\alpha$ signaling," Hypertension, vol. 55, no. 5, pp. 1246-1253, 2010.

[26] M. L. Fu, H. Herlitz, W. Schulze et al., "Autoantibodies against the angiotensin receptor (AT1) in patients with hypertension," Journal of Hypertension, vol. 18, no. 7, pp. 945-953, 2000.

[27] F. Zhu, Y. Sun, M. Wang et al., "Correlation between HLADRB1, HLA-DQB1 polymorphism and autoantibodies against angiotensin $\mathrm{AT}(1)$ receptors in Chinese patients with essential hypertension," Clinical Cardiology, vol. 34, no. 5, pp. 302-308, 2011.

[28] Y. H. Liao, Y. M. Wei, M. Wang, Z. H. Wang, H. T. Yuan, and L. X. Cheng, "Autoantibodies against AT1-receptor and $\alpha 1$ adrenergic receptor in patients with hypertension," Hypertension Research, vol. 25, no. 4, pp. 641-646, 2002.

[29] Y. Sun, Y. Liao, Y. Yuan et al., "Influence of autoantibodies against AT1 receptor and AGTR1 polymorphisms on candesartan-based antihypertensive regimen: results from the Study of Optimal Treatment in Hypertensive Patients with AntiAT1-Receptor Autoantibodies trial," Journal of the American Society of Hypertension, vol. 8, no. 1, pp. 21-27, 2014.

[30] F. Wei, X. J. Jia, S. Q. Yu et al., "Candesartan versus imidapril in hypertension: a randomised study to assess effects of anti-AT1 receptor autoantibodies," Heart, vol. 97, no. 6, pp. 479-484, 2011.

[31] J. L. Reid, "Alpha-adrenergic receptors and blood pressure control," The American Journal of Cardiology, vol. 57, no. 9, pp. 6E-12E, 1986.

[32] M. T. Piascik and D. M. Perez, " $\alpha 1$-adrenergic receptors: new insights and directions," Journal of Pharmacology and Experimental Therapeutics, vol. 298, no. 2, pp. 403-410, 2001. 
[33] H. P. Luther, V. Homuth, and G. Wallukat, " $\alpha 1$-Adrenergic receptor antibodies in patients with primary hypertension," Hypertension, vol. 29, no. 2, pp. 678-682, 1997.

[34] M. L. Fu, H. Herlitz, G. Wallukat et al., "Functional autoimmune epitope on $\alpha 1$-adrenergic receptors in patients with malignant hypertension," The Lancet, vol. 344, no. 8938, pp. 1660-1663, 1994.

[35] K. Wenzel, H. Haase, G. Wallukat et al., "Potential relevance of $\alpha 1$-Adrenergic receptor autoantibodies in refractory hypertension," PLoS ONE, vol. 3, no. 11, Article ID e3742, 2008.

[36] K. P. Minneman, R. N. Pittman, and P. B. Molinoff, "Betaadrenergic receptor subtypes: properties, distribution, and regulation," Annual Review of Neuroscience, vol. 4, pp. 419-461, 1981.

[37] M. A. van Baak, H. A. J. Struyker Boudier, and J. F. M. Smits, "Antihypertensive mechanisms of beta-adrenoceptor blockade: a review," Clinical and Experimental Hypertension A Theory and Practice, vol. 7, no. 1, pp. 1-72, 1985.

[38] G. Wallukat, I. E. Blasig, R. Morwinski, H. J. Herrmann, and E. Rohde, "The sera of spontaneously hypertensive rats contain agonistic auto-antibodies against the $\beta 1$-adrenoceptor," Journal of Hypertension, vol. 13, no. 9, pp. 1031-1036, 1995.

[39] R. Jahns, V. Boivin, L. Hein et al., "Direct evidence for a $\beta 1-$ adrenergic receptor-directed autoimmune attack as a cause of idiopathic dilated cardiomyopathy," Journal of Clinical Investigation, vol. 113, no. 10, pp. 1419-1429, 2004.

[40] Y. Magnusson, G. Wallukat, F. Waagstein, Å. Hjalmarson, and J. Hoebeke, "Autoimmunity in idiopathic dilated cardiomyopathy: characterization of antibodies against the $\beta 1$-adrenoceptor with positive chronotropic effect," Circulation, vol. 89, no. 6, pp. 2760-2767, 1994.

[41] W. A. Catterall, "Voltage-gated calcium channels," Cold Spring Harbor perspectives in biology, vol. 3, no. 8, Article ID a003947, 2011.

[42] D. W. Wilde, P. B. Furspan, and J. F. Szocik, "Calcium current in smooth muscle cells from normotensive and genetically hypertensive rats," Hypertension, vol. 24, no. 6, pp. 739-746, 1994.

[43] R. H. Cox and I. M. Lozinskaya, "Augmented calcium currents in mesenteric artery branches of the spontaneously hypertensive rats," Hypertension, vol. 26, no. 6, pp. 1060-1064, 1995.

[44] Y. Ohya, T. Tsuchihashi, S. Kagiyama, I. Abe, and M. Fujishima, "Single L-type calcium channels in smooth muscle cells from resistance arteries of spontaneously hypertensive rats," Hypertension, vol. 31, no. 5, pp. 1125-1129, 1998.

[45] J. M. Simard, X. Li, and K. Tewari, "Increase in functional Ca2+ channels in cerebral smooth muscle with renal hypertension," Circulation Research, vol. 82, no. 12, pp. 1330-1337, 1998.

[46] A. Pesic, J. A. Madden, M. Pesic, and N. J. Rusch, "High blood pressure upregulates arterial L-type Ca2+ channels: is membrane depolarization the signal?" Circulation research, vol. 94, no. 10, pp. e97-e104, 2004.

[47] P. F. Pratt, S. Bonnet, L. M. Ludwig, P. Bonnet, and N. J. Rusch, "Upregulation of L-type Ca2+ channels in mesenteric and skeletal arteries of SHR," Hypertension, vol. 40, no. 2, pp. 214-219, 2002.

[48] D. J. Triggle, "L-type calcium channels," Current Pharmaceutical Design, vol. 12, no. 4, pp. 443-457, 2006.

[49] Z. H. Zhou, J. Wang, H. Xiao et al., "A novel autoantibody in patients with primary hypertension: antibody against L-type Ca2+ channel," Chinese Medical Journal, vol. 121, no. 16, pp. 1513-1517, 2008.
[50] C. Bason, R. Lorini, C. Lunardi et al., "In type 1 diabetes a subset of anti-coxsackievirus B4 antibodies recognize autoantigens and induce apoptosis of pancreatic beta cells," PLOS ONE, vol. 8, no. 2, Article ID e57729, 2013.

[51] M. J. Schlesinger, "Heat shock proteins," Journal of Biological Chemistry, vol. 265, no. 21, pp. 12111-12114, 1990.

[52] Q. Xu, G. Schett, C. Li, Y. Hu, and G. Wick, "Mechanical stressinduced heat shock protein 70 expression in vascular smooth muscle cells is regulated by rac and ras small $\mathrm{G}$ proteins but not mitogen-activated protein kinases," Circulation Research, vol. 86, no. 11, pp. 1122-1128, 2000.

[53] Q. Xu, D. G. Li, N. J. Holbrook, and R. Udelsman, "Acute hypertension induces heat-shock protein 70 gene expression in rat aorta," Circulation, vol. 92, no. 5, pp. 1223-1229, 1995.

[54] D. F. Liao, Z. G. Jin, A. S. Baas et al., "Purification and identification of secreted oxidative stress-induced factors from vascular smooth muscle cells," Journal of Biological Chemistry, vol. 275, no. 1, pp. 189-196, 2000.

[55] G. Parra, Y. Quiroz, J. Salazar et al., "Experimental induction of salt-sensitive hypertension is associated with lymphocyte proliferative response to HSP70," Kidney International, vol. 74, no. 111, pp. S55-S59, 2008.

[56] N. Ishizaka, T. Aizawa, M. Ohno et al., "Regulation and localization of HSP70 and HSP25 in the kidney of rats undergoing long-term administration of Angiotensin II," Hypertension, vol. 39, no. 1, pp. 122-128, 2002.

[57] H. Pons, A. Ferrebuz, Y. Quiroz et al., "Immune reactivity to heat shock protein 70 expressed in the kidney is cause of saltsensitive hypertension," The American Journal of PhysiologyRenal Physiology, vol. 304, no. 3, pp. F289-F299, 2013.

[58] A. Molvarec, Z. Prohászka, B. Nagy et al., "Association of elevated serum heat-shock protein 70 concentration with transient hypertension of pregnancy, preeclampsia and superimposed preeclampsia: a case-control study," Journal of Human Hypertension, vol. 20, no. 10, pp. 780-786, 2006.

[59] T. Wu, J. Ma, S. Chen et al., "Association of plasma antibodies against the inducible Hsp70 with hypertension and harsh working conditions," Cell Stress \& Chaperones, vol. 6, no. 4, pp. 394-401, 2001.

[60] A. G. Pockley, U. de Faire, R. Kiessling, C. Lemne, T. Thulin, and J. Frostegård, "Circulating heat shock protein and heat shock protein antibody levels in established hypertension," Journal of Hypertension, vol. 20, no. 9, pp. 1815-1820, 2002.

[61] A. Molvarec, Z. Derzsy, J. Kocsis et al., "Circulating anti-heatshock-protein antibodies in normal pregnancy and preeclampsia," Cell Stress and Chaperones, vol. 14, no. 5, pp. 491-498, 2009.

[62] R. Wu, U. de Faire, C. Lemne, J. L. Witztum, and J. Frostegård, "Autoantibodies to OxLDL are decreased in individuals with borderline hypertension," Hypertension, vol. 33, no. 1 I, pp. 5359, 1999.

[63] J. Frostegard, R. Wu, C. Lemne et al., "Circulating oxidized low-density lipoprotein is increased in hypertension," Clinical Science, vol. 105, no. 5, pp. 615-620, 2003.

[64] D. P. Papadopoulos, T. K. Makris, P. Krespi et al., "Antiendothelial cell antibody levels in healthy normotensives with high normal blood pressure," Clinical and Experimental Hypertension, vol. 28, no. 8, pp. 663-667, 2006.

[65] D. P. Papadopoulos, T. K. Makris, U. Papazachou, M. Daskalaki, E. Sanidas, and V. E. Votteas, "Antiendothelial cell antibody levels in patients with masked hypertension," International Journal of Cardiology, vol. 130, no. 3, pp. 405-408, 2008. 
[66] J. Frostegård, R. Wu, C. Gillis-Haegerstrand, C. Lemne, and U. de Faire, "Antibodies to endothelial cells in borderline hypertension," Circulation, vol. 98, no. 11, pp. 1092-1098, 1998.

[67] V. J. Rappaport, G. Hirata, H. K. Yap, and S. C. Jordan, "Antivascular endothelial cell antibodies in severe preeclampsia," The American Journal of Obstetrics and Gynecology, vol. 162, no. 1, pp. 138-146, 1990.

[68] D. G. Harrison, T. J. Guzik, H. E. Lob et al., "Inflammation, immunity, and hypertension," Hypertension, vol. 57, no. 2, pp. 132-140, 2011.

[69] D. G. Harrison, A. Vinh, H. Lob, and M. S. Madhur, "Role of the adaptive immune system in hypertension," Current Opinion in Pharmacology, vol. 10, no. 2, pp. 203-207, 2010.

[70] M. B. Oldstone, "Molecular mimicry and immune-mediated diseases," The FASEB Journal, vol. 12, no. 13, pp. 1255-1265, 1998.

[71] F. Herse, S. Verlohren, K. Wenzel et al., "Prevalence of agonistic autoantibodies against the angiotensin II type 1 receptor and soluble fms-like tyrosine kinase 1 in a gestational age-matched case study," Hypertension, vol. 53, no. 2, pp. 393-398, 2009.

[72] J. R. Kerr, "Parvovirus B19 infection," European Journal of Clinical Microbiology and Infectious Diseases, vol. 15, no. 1, pp. 10-29, 1996.

[73] C. Lunardi, E. Tinazzi, C. Bason, M. Dolcino, R. Corrocher, and A. Puccetti, "Human parvovirus B19 infection and autoimmunity," Autoimmunity Reviews, vol. 8, no. 2, pp. 116-120, 2008.

[74] B. Lamarca, K. Wallace, and J. Granger, "Role of angiotensin II type i receptor agonistic autoantibodies (AT1-AA) in preeclampsia," Current Opinion in Pharmacology, vol. 11, no. 2, pp. 175-179, 2011.

[75] L. Liu, Y. Liu, W. Tong et al., "Pathogen burden in essential hypertension," Circulation Journal, vol. 71, no. 11, pp. 1761-1764, 2007.

[76] I. Ferrari, M. J. Levin, G. Wallukat et al., "Molecular mimicry between the immunodominant ribosomal protein P0 of Trypanosoma cruzi and a functional epitope on the human $\beta 1$ adrenergic receptor," Journal of Experimental Medicine, vol. 182, no. 1, pp. 59-65, 1995.

[77] P. Lopez Bergami, J. Scaglione, and M. J. Levin, "Antibodies against the carboxyl-terminal end of the Trypanosoma cruzi ribosomal P proteins are pathogenic," The FASEB Journal, vol. 15, no. 14, pp. 2602-2612, 2001.

[78] D. Kaplan, I. Ferrari, P. L. Bergami et al., "Antibodies to ribosomal P proteins of Trypanosoma cruzi in Chagas disease possess functional autoreactivity with heart tissue and differ from anti-P autoantibodies in lupus," Proceedings of the National Academy of Sciences of the United States of America, vol. 94, no. 19, pp. 10301-10306, 1997.

[79] A. Mijares, L. Verdot, N. Peineau, B. Vray, J. Hoebeke, and J. Argibay, "Antibodies from Trypanosoma cruzi infected mice recognize the second extracellular loop of the $\beta 1$-adrenergic and M2-muscarinic receptors and regulate calcium channels in isolated cardiomyocytes," Molecular and Cellular Biochemistry, vol. 163-164, pp. 107-112, 1996.

[80] M. E. Malo and L. Fliegel, "Physiological role and regulation of the $\mathrm{Na}+/ \mathrm{H}+$ exchanger," Canadian Journal of Physiology and Pharmacology, vol. 84, no. 11, pp. 1081-1095, 2006.

[81] D. Rosskopf, R. Dusing, and W. Siffert, "Membrane sodiumproton exchange and primary hypertension," Hypertension, vol. 21, no. 5, pp. 607-617, 1993.

[82] D. Rosskopf, E. Fromter, and W. Siffert, "Hypertensive sodiumproton exchanger phenotype persists in immortalized lymphoblasts from essential hypertensive patients. A cell culture model for human hypertension," Journal of Clinical Investigation, vol. 92, no. 5, pp. 2553-2559, 1993.

[83] D. Rosskopf, K. Hartung, J. Hense, and W. Siffert, "Enhanced immunoglobulin formation of immortalized B cells from hypertensive patients," Hypertension, vol. 26, no. 3, pp. 432-435, 1995.

[84] W. Siffert, D. Rosskopf, A. Moritz et al., "Enhanced G protein activation in immortalized lymphoblasts from patients with essential hypertension," Journal of Clinical Investigation, vol. 96, no. 2, pp. 759-766, 1995.

[85] V. N. Phan, M. Kusuhara, P. A. Lucchesi, and B. C. Berk, "A 90-kD NA+-H+ exchanger kinase has increased activity in spontaneously hypertensive rat vascular smooth muscle cells," Hypertension, vol. 29, no. 6, pp. 1265-1272, 1997.

[86] E. Takahashi, J. I. Abe, and B. C. Berk, "Angiotensin II stimulates p90(rsk) in vascular smooth muscle cells: a potential $\mathrm{Na}+-\mathrm{H}+$ exchanger kinase," Circulation Research, vol. 81, no. 2, pp. 268273, 1997.

[87] S. Gunasegaram, R. S. Haworth, D. J. Hearse, and M. Avkiran, "Regulation of sarcolemmal $\mathrm{Na}+\mathrm{H}+$ exchanger activity by angiotensin II in adult rat ventricular myocytes opposing actions via AT1 versus AT2 receptors," Circulation Research, vol. 85, no. 10, pp. 919-930, 1999.

[88] J. D. Zhang, M. B. Patel, Y. S. Song et al., "A Novel role for type 1 angiotensin receptors on T lymphocytes to limit target organ damage in hypertension," Circulation Research, vol. 110, no. 12, pp. 1604-1617, 2012.

[89] T. J. Guzik, N. E. Hoch, K. A. Brown et al., "Role of the T cell in the genesis of angiotensin II-induced hypertension and vascular dysfunction," Journal of Experimental Medicine, vol. 204, no. 10, pp. 2449-2460, 2007.

[90] C. Lagresle-Peyrou, F. Yates, M. Malassis-Séris et al., "Longterm immune reconstitution in RAG-1-deficient mice treated by retroviral gene therapy: a balance between efficiency and toxicity," Blood, vol. 107, no. 1, pp. 63-72, 2006.

[91] S. R. Novotny, K. Wallace, J. Heath et al., "Activating autoantibodies to the angiotensin II type I receptor play an important role in mediating hypertension in response to adoptive transfer of CD4+ T lymphocytes from placental ischemic rats," The American Journal of Physiology-Regulatory Integrative and Comparative Physiology, vol. 302, no. 10, pp. R1197-R1201, 2012.

[92] P. Maurer and M. F. Bachmann, "Immunization against angiotensins for the treatment of hypertension," Clinical Immunology, vol. 134, no. 1, pp. 89-95, 2010.

[93] T. H. Do, Y. Chen, V. T. Nguyen, and S. Phisitkul, "Vaccines in the management of hypertension," Expert Opinion on Biological Therapy, vol. 10, no. 7, pp. 1077-1087, 2010.

[94] M. J. Brown, "Success and failure of vaccines against reninangiotensin system components," Nature Reviews Cardiology, vol. 6, no. 10, pp. 639-647, 2009.

[95] M. Ramos-Casals, I. Sanz, X. Bosch, J. H. Stone, and M. A. Khamashta, "B-cell-depleting therapy in systemic lupus erythematosus," The American Journal of Medicine, vol. 125, no. 4, pp. 327-336, 2012.

[96] M. D. Esler, H. Krum, M. Schlaich, R. E. Schmieder, M. Böhm, and P. A. Sobotka, "Renal sympathetic denervation for treatment of drug-resistant hypertension: one-year results from the symplicity htn-2 randomized, controlled trial," Circulation, vol. 126, no. 25, pp. 2976-2982, 2012.

[97] D. L. Bhatt, D. E. Kandzari, W. W. O’Neill et al., “A controlled trial of renal denervation for resistant hypertension," The New England Journal of Medicine, vol. 370, no. 15, pp. 1393-1401, 2014. 


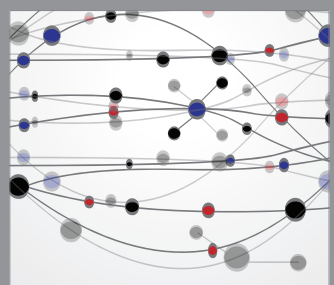

The Scientific World Journal
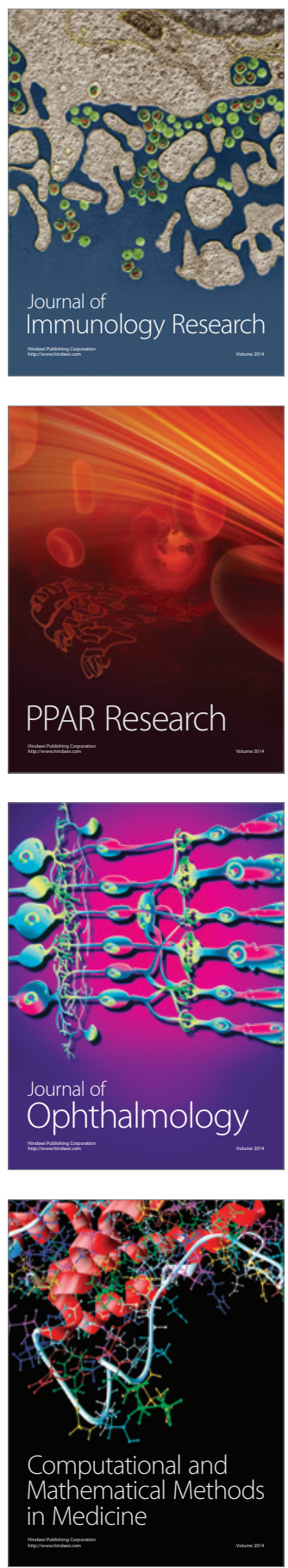

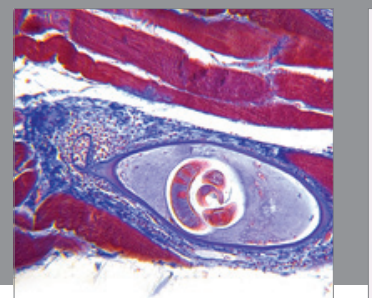

Gastroenterology

Research and Practice
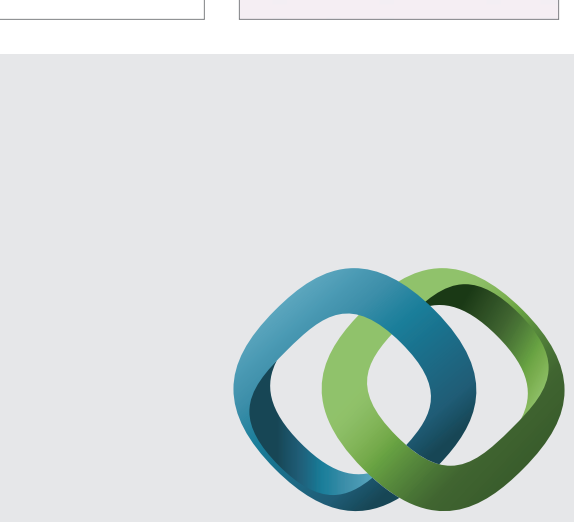

\section{Hindawi}

Submit your manuscripts at

http://www.hindawi.com
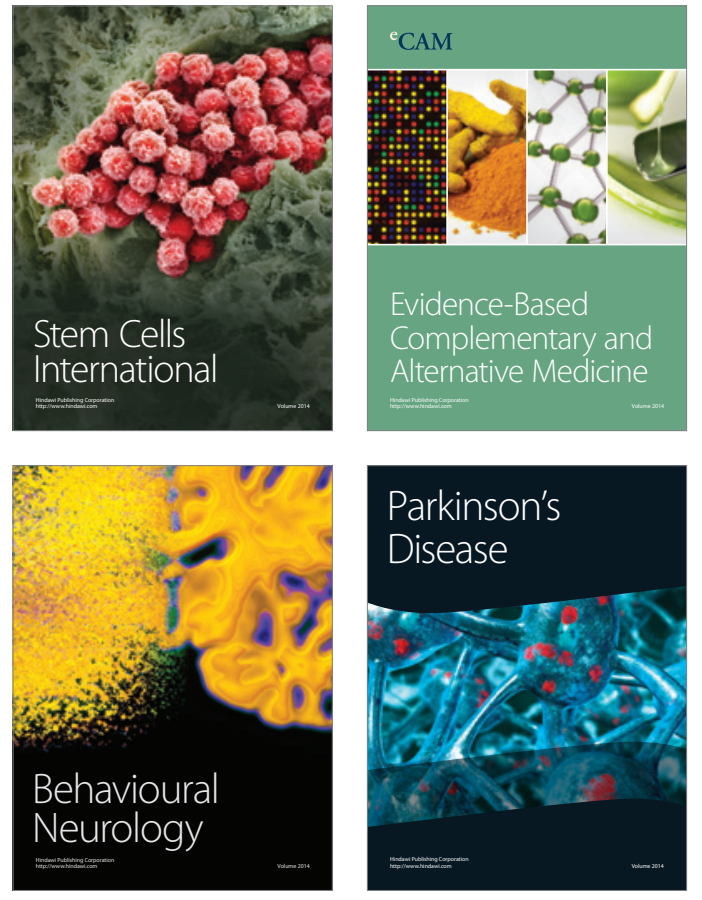
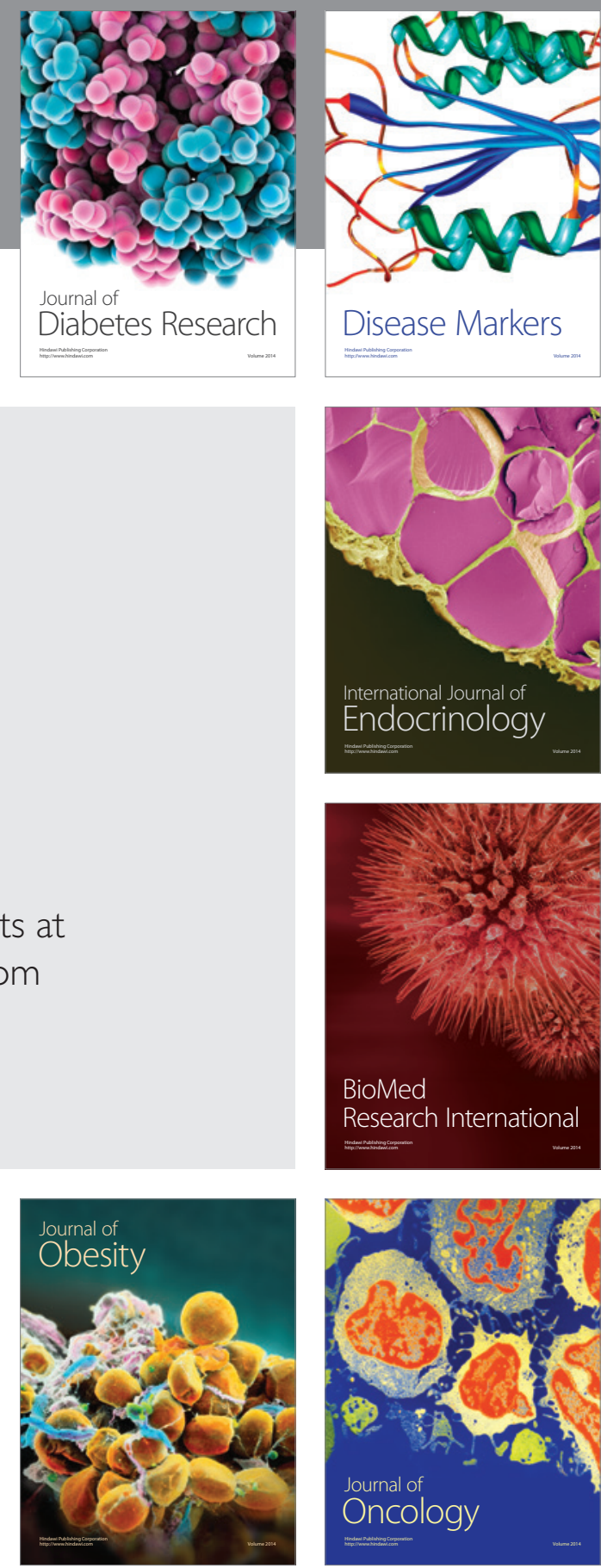

Disease Markers
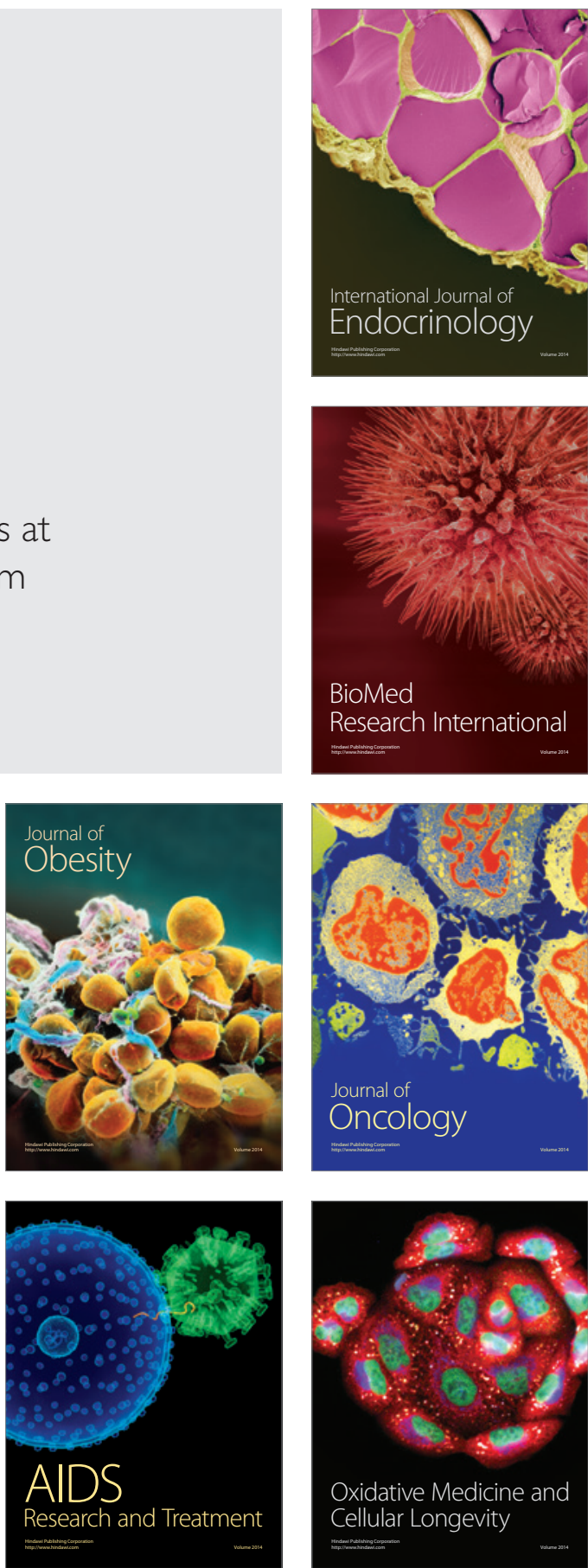